\title{
International tracking of the COVID-19 invasion: an amazing example of a globalized scientific coordination effort
}

\author{
Cleo Bertelsmeier $\mathbb{D} \cdot$ Sébastien Ollier
}

Received: 10 April 2020/Accepted: 14 May 2020/Published online: 19 May 2020

(C) Springer Nature Switzerland AG 2020

\begin{abstract}
It is extraordinary to witness the spread of COVID-19 almost in real-time. This tight monitoring of the invasion of a new virus is a situation that most other invasion scientists could only dream of. Especially spatiotemporal spread data of the early phases of an invasion would be extremely useful in order to understand and predict the human-mediated spread of species around the globe. So far, invasive species that directly affect human health, such as the Sars-Cov-2 virus causing COVID-19, have been treated differently from invasive species affecting environmental health. Despite progresses in constructing large checklists of invasive species, these records often enter the databases only decades after the establishment of the organism in a country. This is inadequate to understand ongoing spread dynamics and estimate current invasion risks. Yet, national services often possess extremely useful information about early detections and interceptions of species at air and maritime ports, which could greatly improve predictions and help set management priorities. Considering
\end{abstract}

C. Bertelsmeier ( $\square)$

Department of Ecology and Evolution, University of Lausanne, Le Biophore, 1015 Lausanne, Switzerland e-mail: cleo.bertelsmeier@unil.ch

\section{S. Ollier}

Department of Ecology, Systematics and Evolution, University Paris-Saclay, Bâtiment 362, rue du Doyen André Guinier, 91405 Orsay, France

e-mail: sebastien.ollier@universite-paris-saclay.fr the massive impacts of invasive species, it is time to move on to such a collaborative way of handling invasion data. Invasive insects, birds, mammals, fungi, and other species are the result of globalization and call for a globalized response, exactly like the COVID-19 pandemic.

Keywords COVID-19 - Infectious disease · Invasions · Biosecurity · International policy · Port of entry $\cdot$ Interceptions

It is extraordinary to witness the spread of COVID-19 almost in real-time. One can follow daily news about the number of new cases and deaths resulting from this respiratory disease since its very beginning in China to several hundreds of thousands of cases in over one hundred countries worldwide. Although most citizens take this information for granted, it is actually the result of a remarkable international open data-sharing policy. International health regulations require countries to inform the World Health Organization (WHO) of any event that may have implications for international public health (World Health Organization 2005). As a result, WHO is able to publish a database of cases and their geographic locations with daily updates. The data on the spread of COVID-19 are openly accessible to researchers who can build maps and mathematically model the spread of the disease to 
make predictions about potential future spread under different scenarios (Dong et al. 2020).

This tight monitoring of the invasion of a new virus is a situation that most other invasion scientists could only dream of. Especially spatiotemporal spread data of the early phases of an invasion would be extremely useful in order to understand and predict the humanmediated spread of species around the globe. There are thousands of invasive species, including mammals, birds, fish, amphibians, insects, microbes, fungi, and viruses, that constitute a major threat to biodiversity, agriculture, health, and the economy, especially in the least developed countries (Early et al. 2016). However, invasive species that directly affect human health, such as the Sars-Cov-2 virus causing COVID-19, have been treated differently from invasive species affecting environmental health (Martinou and Roy 2018). Calls have long been made to implement an international "biosecurity strategy" covering infectious diseases and other invasive organisms to address common issues such as coordination across governments and other institutions at all levels (Meyerson and Reaser 2002). However, there are still no international mechanisms or regulations to address collective environmental risks posed by invasive species that do not necessarily affect human health and that are introduced by the global commodity trade (Keller and Perrings 2011).

The scientific community has made progresses in constructing large checklists and databases of invasive species, for example Delivering Alien Invasive Species Inventories for Europe (DAISIE, European Commission 2010), the IUCN Global Invasive Species database (GISD, IUCN 2020) or the Global Register of Introduced and Invasive Species (GRIIS, Pagad et al. 2018), which enable invasion scientists to map largescale patterns (Essl et al. 2011; Dawson et al. 2017; Dyer et al. 2017; Turbelin et al. 2017) and to study the intercontinental exchanges of species (Van Kleunen et al. 2015; Capinha et al. 2017). But an important difference with the COVID-19 updates is the timescale: there are frequently long time lags between arrival of an organism, detection, and invasion (Coutts et al. 2017). Therefore, records often enter the database only decades after the establishment of the organism in a country. This is inadequate to understand ongoing spread dynamics and estimate current invasion risks. For example, a country that has received an invasive species may already serve as source of new additional invasions, via the so-called bridgehead effect (Bertelsmeier and Keller 2018), even before the invasion is known to scientists. Yet, national services often possess extremely useful information about early detections and interceptions of species at air and maritime ports, which could greatly improve predictions and help set management priorities. The international sharing of COVID-19 data, especially in its earliest stages, is impressive and should serve as an example for tracking other invasive organisms (although the international response to manage this infectious disease may have been less coordinated). Considering the massive impacts of invasive species and associated costs of more than several hundred billion US dollars annually (Pimentel 2011), it is time to move on to such a collaborative way of handling invasion data. Invasive insects, birds, mammals, fungi, and other species are the result of globalization and call for a globalized response, exactly like the COVID-19 pandemic.

\section{References}

Bertelsmeier C, Keller L (2018) Bridgehead effects and role of adaptive evolution in invasive populations. Trends Ecol Evol 33:527-534

Capinha C, Seebens H, Cassey P et al (2017) Diversity, biogeography and the global flows of alien amphibians and reptiles. Divers Distrib 23:1313-1322

Coutts SR, Helmstedt KJ, Bennett JR (2017) Invasion lags: the stories we tell ourselves and our inability to infer process from pattern. Divers Distrib 1:1-8

Dawson W, Moser D, Van Kleunen M et al (2017) Global hotspots and correlates of alien species richness across taxonomic groups. Nat Ecol Evol 1:1-7

Dong E, Du H, Gardner L (2020) An interactive web-based dashboard to track COVID-19 in real time. Lancet Infect Dis 3099:19-20

Dyer EE, Cassey P, Redding DW et al (2017) The global distribution and drivers of alien bird species introduction and richness. PLoS Biol 15:e2000942

Early R, Bradley BA, Dukes JS et al (2016) Global threats from invasive alien species in the twenty-first century and national response capacities. Nat Commun 7:12485

Essl F, Dullinger S, Rabitsch W et al (2011) Socioeconomic legacy yields an invasion debt. Proc Natl Acad Sci USA 108:203-207

European Commission (2010) Delivering alien invasive species inventories for Europe (DAISIE). http://www.europealiens.org/

IUCN (2020). In: Global invasive species database. http://www. iucngisd.org/gisd/ 
Keller RP, Perrings C (2011) International policy options for reducing the environmental impacts of invasive species. Bioscience 61:1005-1012

Martinou AF, Roy HE (2018) From local strategy to global frameworks: effects of invasive alien species on health and well-being. In: Mazza G, Tricarico E (eds) Invasive species and human health. CABI, Wallingford

Meyerson LA, Reaser JK (2002) A unified definition of biosecurity. Science 80(295):44

Pagad S, Genovesi P, Carnevali L et al (2018) Introducing the global register of introduced and invasive species. Sci Data 5:170202

Pimentel D (2011) Biological invasions-economic and environmental costs of alien plant, animal, and microbe species. CRC Press, Boca Raton
Turbelin AJ, Malamud BD, Francis RA (2017) Mapping the global state of invasive alien species: patterns of invasion and policy responses. Glob Ecol Biogeogr 26:78-92

Van Kleunen M, Dawson W, Essl F et al (2015) Global exchange and accumulation of non-native plants. Nature 525:100-103

World Health Organization (2005) International health regulations (2005). World Health Organization, Geneva

Publisher's Note Springer Nature remains neutral with regard to jurisdictional claims in published maps and institutional affiliations. 